\title{
Evaluation of important credit risk factors in the SME segment
}

\author{
Ján Dvorský \\ Faculty of Management and Economics, Tomas Bata University in Zlin, \\ Czech Republic \\ j1dvorsky@fame.utb.cz. \\ Jaroslav Schönfeld \\ Faculty of Business Administration, University of Economics, \\ Czech Republic \\ schonfeld@vse.cz.
}

\section{Anna Kotásková}

Faculty of Economics and Business, Paneuropean University in Bratislava, Slovak Republic

anna.kotaskova@gmail.com

\section{Zora Petráková}

Faculty of Civil Engineering, Slovak University of Technology

Slovak Republic

rora.petrakova@stuba.sk

Abstract. The aim of the paper is to define important credit risk factors in the SME segment, find out how entrepreneurs evaluate these factors, and quantify the differences in their evaluation based on the enterprise's age, gender and attained education level. An empirical research was conducted in relation to the defined aim. 1,141 responses were received by means of the online questionnaire. To process the results, the two-sample t-test was used. Statistical tools such as histogram, Q-Q graph, z-test, and goodness-of-fit tests were applied to verify the assumptions. The results indicate that small and medium-sized enterprises perceive credit risk more intensively in comparison with the pre-crisis era. It was also discovered that the SMEs' knowledge of credit criteria is somewhat low. Entrepreneurs also state that banks' credit criteria are not very transparent. Based on the findings, the length of operating a business has a significant influence on the evaluation of credit risk factors. Experienced entrepreneurs, meaning those operating a business for over 10 years, have a more intense perception of the significance of credit risk, they also have better knowledge of banks' credit criteria, and view credit criteria as more transparent than beginner entrepreneurs. 
An interesting finding is that the length of operating a business reduces the differences in the evaluation of important credit risk factors in regard to entrepreneurs' gender and age.

Keywords: small and medium-sized enterprises, credit risk, banks, company's age, gender, education of businesspersons.

JEL Classification: L26

\section{INTRODUCTION}

Business environment of small and medium-sized enterprises (SMEs) is a popular area for both theoretical research and practical investigations in the European Union.

One of frequently discussed topics by many authors is SMEs' credit risk in relation to their need for external financing via bank loans (Armstrong et al., 2013; Beck, 2013; Belas et al., 2014; Dobeš et al., 2017; Kozubikova et al., 2015, 2017; Kljucnikov et al., 2016; Yasnolob, \& Radionova, 2017; and other authors).

The relationship between financial institutions and active enterprises is influenced by many risk factors. Credit risk presents the possibility that debtors will not be able to fulfill their commitments stemming from their relationship with a creditor in a timely manner, if at all.

From the banks' perspective, the causes of credit risk can be divided into several sub-causes related to banks' own decisions: credit criteria towards entrepreneurs (Belás et al., 2017; Karaev et al., 2017), client's credit rating (Greene \& Saridakis, 2008), measuring default (Balcerzak et al., 2017; Kliestik et al., 2018; Kliestikova et al., 2018; Maciag \& Löderbusch, 2017; Siekelova et al., 2017; Gavurova et al., 2017), credit risk duration (Haghani, 2016), and others. Other types of causes are those stemming from the development of political and economic situation in a respective country (Perez et al., 2017).

The originality of this paper lies in the detailed research of entrepreneurs' notions about important credit risk factors based on the defined criteria such as age of the enterprise as well as ' gender and attained education level. The assumption is that these parameters significantly influence the entrepreneurs' attitude towards managing credit risk, and can serve as an important impulse for banks in their process of innovating credit criteria.

The structure of the paper is as follows: The first chapter presents current findings in the researched area. The second part defines the aim of the paper, the research methodology, and the data used. The Results and Discussion part presents the results of the empirical research and comparison with other results. The conclusion offers a final summary of the research.

\section{SHORT LITERATURE REVIEW}

Credit risk can be influenced by both external and internal factors (Pavlov et al., 2015).

Gorzen-Mitka (2015) Mentel \& Brożyna (2015) states that risk is inherent in all business functions and in every kind of activity. Small and medium-sized enterprises (SMEs) are particularly vulnerable to continuous daily internal and external undesirable events that adversely affect business performance. Among the disturbances, some are likely to create risks to the enterprises in terms of loss of production, manufacturing capability, human resources, market share, and economic losses.

Other authors claim that small and medium-sized enterprises (SMEs) are increasingly aware of the benefits of closing loops and improving resource efficiency, such as saving material costs, creating competitive advantages, and accessing new markets. At the same time, however, various barriers (factors) 
pose challenges to small businesses in their transition to a circular economy, namely lack of financial resources and lack of technical skills (Rizos et all, 2016).

Yildirim, Akci, and Eksi (2013) and Mardika, Damayanti, and Supramono (2018) have examined the firm-specific characteristics that affect the access to credit from banks for SMEs. They find that SMEs with a larger asset base can have more access to formal credit than SMEs with a small asset base, as a larger asset base can signal the bank that the SME will be able to pay the extended loans by liquidating the assets (compare Cwynar et al, 2016). Higher asset turnover and international trade activities are positively associated with higher possibilities for SMEs to get credit from the banks. However, they do not find any significant relationship between the age of the enterprise and availability of credit.

In this context Neuberger and Räthke (2009) state that micro-enterprises are especially predisposed to incorrect selection and moral hazard, and therefore their access to debt financing is limited. Small enterprises are characterized by higher Business Administration and Management information asymmetry and credit risk.

An important condition of effective SMEs financing via bank loans is transparent conduct by all parties involved (European Association of Craft, Small and medium-sized Enterprises, 2007; Bain \& Company, Inc. and the Institute of International Finance, 2013). SME should provide true and correct information, as these are entered into commercial banks' rating models, and banks should use transparent criteria when granting loans.

The survey showed that young SMEs were twice as likely credit constrained than established enterprises. More importantly, $17.1 \%$ of young firms did not receive any form of finance from the bank. On top of that, $13.5 \%$ young SMEs reported the problem of accessing bank finance, compared to $2.5 \%$ of established SMEs. Hence, it is possible to say that business age has a significant impact on bank financing in the Scottish market (North, Baldock, and Ekanem, 2010).

Although the European Committee and the European Central Bank show institutional effort and provide international support in the form of statistical and economic analyses related to credit risk in the SME segment, their results only provide a limited scope of the subject matter, one of the reasons being target limitations of researches mapping the issue in the SME segment on an aggregate scale. Their analyses lack differentiation of SMEs based on their age, entrepreneurs' gender and attained education level, etc. These facts are important to detect motives and attitudes, as well as their development throughout an enterprise's lifespan. A positive fact is that some scientific researches do examine these factors and create an explicit research and analytical framework for further research. The following studies are used in this paper:

According to Global Markets Institute (2014), SMEs owned and managed by women were more credit constrained than the men owned SMEs. In this context Kreiser et al. (2010) state that enterprises with male managers have more risk taking behavior than any other firms. Similar findings were also presented by Ayub et al. (2013).

Higher level of attained education significantly and positively influences the SMEs' financial performance (Van der Sluis, and Van Praag, 2008). According to Kato, Okamuro, and Honjo (2015), an entrepreneur with a university degree can easily find different sources of capital which he can invest in research and development, hence increasing the innovation of the small business in a specific market.

Carter, Shaw, Lam \& Wilson (2007) examined the effect of gender on the bank lending process to small businesses. They have found that in the process of considering an application, the applicant's education plays an important role, and a lower level of attained education of a female applicant is mostly rejected. However, when considering a higher level of attained education, the gender criteria for loan processing diminishes. When the loan applicant is male, the loan officer is most likely to know about the business plan, financial history, and general characteristics of the applicant. On the other hand, when a 
female is applying for the loan, the officers are more interested in knowing whether she has done enough research, and her educational background is mostly discussed.

Rad, Yazdanfar, and Öhman (2014) demonstrated that female loan officers focus more on collateral (used as a proxy for risk aversion) in their evaluations of first-time loan applications than male loan officers. However, the findings also suggest that there are no significant differences between the two groups as far as risk aversion when they evaluate additional loan applications. Other variables (age, tenure, insight, education, and location) did not significantly affect the loan officers' risk aversion.

Irwin \& Scott (2010) examined the barriers faced by SMEs in raising bank finance in the UK. More specifically, they have examined personal characteristics of the entrepreneur in raising bank financing by considering ethnicity, gender, and attained education. Empirical result of the paper shows that $18 \%$ of men faced difficulties in financing their start-ups, compared to $12 \%$ of women. However, the result is not statistically significant at the 5\% level. Still, it suggests that men are more financially constrained than women, due to their past repayment history and less commitment to their businesses.

To create optimal relationships between banks and SMEs, it is important to know entrepreneurs' attitude towards significant credit risk factors, to know how they perceive its growing intensity in a postcrisis era, how familiar they are with commercial banks' credit criteria, and how they evaluate their transparency. These findings are beneficial not only for high-quality benchmarking indicators that enable conducting comparative analyses in the SME segment in different regions, but also for the process of creating platforms for regional and national strategic planning aimed at supporting the economy and regional growth.

\section{AIM, RESEARCH METHODOLOGY AND DATA}

The aim of the paper is to define important credit risk factors in the SME segment, find out how entrepreneurs evaluate these factors, and quantify the differences in their evaluation based on the enterprise's age and the entrepreneurs' gender and attained education level.

An empirical research was conducted in relation to the defined aim in 2015 on a sample of 1,141 respondents in the Czech Republic. The method of choosing companies was as follows: A total of 1650 companies from the Albertina database were randomly selected. These companies were contacted via email, while the business owners were asked to complete a questionnaire. If these companies had not responded to the email, they were approached by telephone. The structure of the respondents was as follows: $75 \%$ men, $25 \%$ women; $48 \%$ of respondents reported that they have secondary education, $34 \%$ had a university degree and $18 \%$ reported that they have secondary education without graduation; $65 \%$ of the total number of companies are microenterprises, $27 \%$ are small enterprises and $8 \%$ are medium-sized enterprises. $62 \%$ of companies' owners stated that the company exists for more than 10 years, $21 \%$ of them stated that they operate a maximum of five years and $17 \%$ of them reported that the company belongs to an interval of five to ten years of existence. Respondents were representing the following sectors: trade (33\%), manufacturing $(23 \%)$, construction $(14 \%)$, transport $(6 \%)$, agriculture $(3 \%)$, and other services $(21 \%)$.

The structure of entrepreneurs' demographic characteristics, operating a business: from 1 to 5 years: by gender: men - 151 (61.4\%), women - 94 (38.4\%); by education: high school education (without leaving exam, with leaving exam) - $143(58.4 \%)$, university education - 102 (41.6\%); from 6 to 10 years: by gender: men - 138 (72.2\%), women - 53 (27.7\%); by education: high school education (without leaving exam, with leaving exam) - 131 (68.6\%), university education - 31.4 (31.4\%); over 10 years: by gender: men - 572 $(81.1 \%)$, women - $133(18.9 \%)$; by education: high school education (without leaving exam, with leaving exam) -475 (67.3\%), university education - $230(32.6 \%)$.

Important credit risk factors $(\mathrm{CRF})$ were defined using the following three statements: 
- The significance of credit risk during business crisis has a growing tendency (CRF1);

- Entrepreneurs have full knowledge of banks' credit criteria for providing loans to SMEs (CRF2);

- Banks' credit criteria for providing financing to entrepreneurs are transparent (CRF3).

The differences in entrepreneurs' notions were examined as follows:

1. The entire pool of respondents was divided into three age groups, by the length of operating a business in the business environment: from 0 to 5 years (Group A), from 6 to 10 years (Group B), and over 10 years (Group C).

2. Entrepreneurs' notions about credit risk factors were compared among groups $A, B$, and $C$.

3. Within each age group (A, B, and C), entrepreneurs' notions were compared based on their gender and attained education level.

The following hypotheses were created in order to achieve the paper's main aim:

H1: Within the defined age groups, there are statistically significant differences in entrepreneurs' notions about important credit risk factors.

H2: Within the defined age groups, there are statistically significant differences in the evaluation of credit risk factors' significance during crisis in regard to the entrepreneurs' gender and attained education level.

H3: Within the defined age groups, there are statistically significant differences in the knowledge of commercial banks' credit criteria in regard to the entrepreneurs' gender and attained education level.

H4: Within the defined age groups, there are statistically significant differences in the evaluation of the transparency of commercial banks' credit criteria in regard to the entrepreneurs' gender and attained education level.

The entrepreneurs were given the option to mark one of the following responses regarding statements about credit risk factors: I completely agree (score $=2$ ), I agree (score $=1$ ), neutral (score $=0)$, I disagree (score $=-1)$, and I completely disagree $($ score $=-2)$.

To evaluate the above mentioned hypotheses, descriptive statistics tools were used in the first step:

a) for testing - contingency tables aimed at sorting enterprises based on two and more statistical characteristics (gender, education, etc.);

b) degree and variability characteristics - absolute and relative count, mean, variance, score. The score is calculated as a sum of quantitative ratings from all entrepreneurs with the selected statistical character.

Z-score calculator for 2 population proportions was used to determine significant statistical differences in entrepreneurs' notions about important credit risk factors (Balcaen and Oeghe, 2006). Level of significance $(\alpha)=0.05$.

The two-sample t-test (unpaired) with identical variances was used to compare entrepreneurs' notions on CRF based on their primary and secondary characteristics. The aim was to test the hypothesis whether the difference between the mean values of sample sets is zero (null hypothesis) as opposed to the non-zero difference between the mean values (alternative hypothesis). All tests were done on the significance level of 0.05. Critical values of accepting or rejecting the null hypothesis using the degrees of freedom number are presented as evaluations of data in the below tables ( $\mathrm{t}$ - Statistics a $\mathrm{p}$-value $(\mathrm{P}(\mathrm{T}<=\mathrm{t})))$. Critical values of testing by: gender $-\mathrm{t}=1.969(0.05,243$ degrees of freedom), attained education level $-\mathrm{t}=1.973(0.05,703$ degrees of freedom). To perform and evaluate the above methodical application of $\mathrm{t}$ - test, it is necessary to verify the following provisions: a) normality of entrepreneurs' evaluations by a selected statistical character; b) independence and equality of variances among entrepreneur samples by a selected statistical character. The verification of the assumptions was done before performing the t-test. Graphical data analysis (Histogram, Q-Q graph) and Goodness-of-fit tests were used to verify the normality assumption. The Ftest was used to verify the assumption of equality of variances among sample sets. The provisions necessary 
to perform the testing using the two-sample t-test with identical variances in selected entrepreneur samples were fulfilled. The calculations were done using the sophisticated SPSS Statistics software.

\section{RESULTS}

Table 1 presents entrepreneurs' evaluation of important SME credit risk factors based on the length of operating a business in the business environment. Positive answers were compared using the Z-score.

Table 1

Evaluation of differences in entrepreneurs' notions about important credit risk factors

\begin{tabular}{|c|c|c|c|c|}
\hline \multirow[b]{2}{*}{ CRF1: } & \multicolumn{3}{|c|}{ Length of operating a business } & \multirow{2}{*}{$\begin{array}{c}\text { Z-score } \\
\mathrm{A} / \mathrm{B} \\
\mathrm{B} / \mathrm{C} \\
\mathrm{A} / \mathrm{C} \\
\end{array}$} \\
\hline & $\begin{array}{c}\text { From } 1 \text { to } 5 \text { years } \\
\text { (A) }\end{array}$ & $\begin{array}{l}\text { From } 6 \text { to } 10 \text { years } \\
\text { (B) }\end{array}$ & $\begin{array}{l}\text { Over } 10 \text { years } \\
(\mathrm{C})\end{array}$ & \\
\hline 1. I completely agree/ratio in $\%$ & $11 / 4.5$ & $19 / 9.9$ & $71 / 10.1$ & \multirow[b]{3}{*}{$\begin{array}{l}0.131 \\
0.258 \\
\mathbf{0 . 0 0 1}\end{array}$} \\
\hline 2. I agree/ratio in $\%$ & $124 / 50.6$ & $100 / 52.4$ & $399 / 56.6$ & \\
\hline $\begin{array}{l}1+2 \\
\text { ratio in } \%\end{array}$ & $\begin{array}{l}135 \\
\mathbf{5 5 . 1}\end{array}$ & $\begin{array}{l}119 \\
62.3\end{array}$ & $\begin{array}{l}470 \\
66.7\end{array}$ & \\
\hline $\begin{array}{l}\text { 3. Neither agree nor disagree/ } \\
\text { ratio in } \%\end{array}$ & $88 / 35.9$ & $51 / 26.7$ & $175 / 24.8$ & \\
\hline 4. I disagree/ratio in $\%$ & $19 / 7.8$ & $19 / 9.9$ & $55 / 7.8$ & \\
\hline 5. I completely disagree/ratio in $\%$ & $3 / 1.2$ & $2 / 1.1$ & $5 / 0.7$ & \\
\hline CRF2 & $\begin{array}{c}\text { From } 1 \text { to } 5 \text { years } \\
\text { (A) }\end{array}$ & $\begin{array}{l}\text { From } 6 \text { to } 10 \text { years } \\
\text { (B) }\end{array}$ & $\begin{array}{l}\text { Over } 10 \text { years } \\
\text { (C) }\end{array}$ & $\begin{array}{l}\mathrm{A} / \mathrm{B} \\
\mathrm{B} / \mathrm{C} \\
\mathrm{A} / \mathrm{C}\end{array}$ \\
\hline 1. I completely agree/ratio in $\%$ & $3 / 1.2$ & $2 / 1.0$ & $14 / 2.0$ & \multirow[b]{3}{*}{$\begin{array}{l}0.992 \\
\mathbf{0 . 0 0 4} \\
\mathbf{0 . 0 0 5}\end{array}$} \\
\hline 2. I agree/ratio in $\%$ & $54 / 22.0$ & $40 / 20.9$ & $218 / 30.9$ & \\
\hline $\begin{array}{l}1+2 \\
\text { ratio in } \%\end{array}$ & $\begin{array}{c}57 \\
23.2\end{array}$ & $\begin{array}{c}42 \\
21.9\end{array}$ & $\begin{array}{l}232 \\
32.9\end{array}$ & \\
\hline $\begin{array}{l}\text { 3. Neither agree nor disagree/ } \\
\text { ratio in } \%\end{array}$ & $84 / 34.3$ & $52 / 27.2$ & $208 / 29.5$ & \\
\hline 4. I disagree/ratio in $\%$ & $94 / 38.4$ & $86 / 45,0$ & $246 / 34.9$ & \\
\hline 5. I completely disagree/ratio in $\%$ & $10 / 4.1$ & $11 / 5.9$ & $19 / 2.7$ & \\
\hline CRF3 & $\begin{array}{c}\text { From } 1 \text { to } 5 \text { years } \\
\text { (A) }\end{array}$ & $\begin{array}{l}\text { From } 6 \text { to } 10 \text { years } \\
\text { (B) }\end{array}$ & $\begin{array}{l}\text { Over } 10 \text { years } \\
\text { (C) }\end{array}$ & $\begin{array}{l}\mathrm{A} / \mathrm{B} \\
\mathrm{B} / \mathrm{C} \\
\mathrm{A} / \mathrm{C} \\
\end{array}$ \\
\hline 1. I completely agree/ratio in $\%$ & $2 / 0.8$ & $2 / 1.0$ & $9 / 1.3$ & \multirow[b]{3}{*}{$\begin{array}{l}0.718 \\
0.153 \\
\mathbf{0 . 0 4 0}\end{array}$} \\
\hline 2. I agree/ratio in $\%$ & $61 / 24.9$ & $50 / 26.2$ & $221 / 31.3$ & \\
\hline $\begin{array}{l}1+2 \\
\text { ratio in } \%\end{array}$ & $\begin{array}{c}63 \\
25.7\end{array}$ & $\begin{array}{c}52 \\
27.2\end{array}$ & $\begin{array}{l}230 \\
32.6\end{array}$ & \\
\hline $\begin{array}{l}\text { 3. Neither agree nor disagree/ } \\
\text { ratio in } \%\end{array}$ & $129 / 52.7$ & $91 / 47.6$ & $318 / 45.1$ & \\
\hline 4. I disagree/ratio in $\%$ & $45 / 18.4$ & $44 / 23.0$ & $149 / 21.1$ & \\
\hline 5. I completely disagree/ratio in $\%$ & $8 / 3.2$ & $4 / 2.2$ & $8 / 1.2$ & \\
\hline
\end{tabular}

Source: Authors' results 
The results (see Table 1) indicate that there are statistically significant differences in the evaluation of all three selected credit risk factors between Group A and Group B (CRF1: P-value = 0.001, CRF2: P-value $=0.005$, CRF3: P-value $=0.040$ ).

It was discovered that the length of operating a business influences the evaluation of important credit risk factors. Entrepreneurs operating a business for over 10 years (Group C) have a higher perception of the influence of credit risk factors in the current era, have better knowledge of banks' credit criteria, and view credit criteria as more transparent than Group A (beginner entrepreneurs).

Hypothesis $\mathrm{H} 1$ is partially accepted.

Table 2 comprises the CRF1 evaluation results in relation to entrepreneur's primary characteristics (length of operating a business) and secondary characteristics (gender and attained education level).

Table 2

Evaluation of credit risk's significance during crisis

\begin{tabular}{|c|c|c|c|c|}
\hline \multicolumn{5}{|c|}{ Length of operating a business from 1 to 5 years } \\
\hline \multirow{2}{*}{ Characteristics } & \multicolumn{2}{|c|}{ Gender } & \multicolumn{2}{|c|}{ Education } \\
\hline & Men & Women & $\mathrm{OE}$ & $\mathrm{UE}$ \\
\hline Number of entrepreneurs & 151 & 94 & 143 & 102 \\
\hline Score & 82 & 39 & 76 & 45 \\
\hline Mean & 0.543 & 0.415 & 0.531 & 0.441 \\
\hline $\mathrm{t}-$ Statistics & \multicolumn{2}{|c|}{1.729} & \multicolumn{2}{|c|}{1.581} \\
\hline $\mathrm{P}(\mathrm{T}<=\mathrm{t})$ & \multicolumn{2}{|c|}{0.042} & \multicolumn{2}{|c|}{0.057} \\
\hline \multicolumn{5}{|c|}{ Length of operating a business from 6 to 10 years } \\
\hline \multirow{2}{*}{ Characteristics } & \multicolumn{2}{|c|}{ Gender } & \multicolumn{2}{|c|}{ Education } \\
\hline & Men & Women & $\mathrm{OE}$ & $\mathrm{UE}$ \\
\hline Number of entrepreneurs & 138 & 53 & 131 & 60 \\
\hline Score & 78 & 37 & 79 & 36 \\
\hline Mean & 0.565 & 0.698 & 0.603 & 0.600 \\
\hline $\mathrm{t}-$ Statistics & \multicolumn{2}{|c|}{2.133} & \multicolumn{2}{|c|}{0.213} \\
\hline $\mathrm{P}(\mathrm{T}<=\mathrm{t})$ & \multicolumn{2}{|c|}{0.017} & \multicolumn{2}{|c|}{0.831} \\
\hline \multicolumn{5}{|c|}{ Length of operating a business over 10 years } \\
\hline \multirow{2}{*}{ Characteristics } & \multicolumn{2}{|c|}{ Gender } & \multicolumn{2}{|c|}{ Education } \\
\hline & Men & Women & $\mathrm{OE}$ & $\mathrm{UE}$ \\
\hline Number of entrepreneurs & 572 & 133 & 475 & 230 \\
\hline Score & 384 & 92 & 330 & 146 \\
\hline Mean & 0.671 & 0.692 & 0.694 & 0.635 \\
\hline $\mathrm{t}-$ Statistics & \multicolumn{2}{|c|}{0.589} & \multicolumn{2}{|c|}{0.981} \\
\hline $\mathrm{P}(\mathrm{T}<=\mathrm{t})$ & \multicolumn{2}{|c|}{0.279} & \multicolumn{2}{|c|}{0.163} \\
\hline
\end{tabular}

Notes: OE - Other education, UE - University education. Source: Authors' results.

There are statistically significant differences in male and female entrepreneurs' notions about the significance of credit risk having a growing tendency during business crisis, in relation to the length of operating a business from 1 to 10 years (length of operating a business from 1 to 5 years: $\mathrm{P}(\mathrm{T}<=\mathrm{t})=0.042$, length of operating a business from 6 to 10 years: $\mathrm{P}(\mathrm{T}<=\mathrm{t})=0.017)$.

Men, as opposed to women (Group A) are more prone to agree with the statement that the significance of credit risk grows during crisis. On the contrary, women in Group B view credit risk as more significant 
during crisis than men. In Group C, entrepreneurs' gender and age had no influence on the evaluation of credit risk factors.

It can be said that the evaluation of the credit risk factor by both men and women depends to a certain degree on the length of operating a business, although this trend cannot be formulated unambiguously.

The highest attained education level has no statistically significant impact on the entrepreneurs' evaluation, regardless of the length of operating a business in the business environment (from 1 to 5 years: $\mathrm{P}(\mathrm{T}<=\mathrm{t}) \geq 0.057$; from 6 to 10 years: $\mathrm{P}(\mathrm{T}<=\mathrm{t}) \geq 0.831$; over 10 years: $\mathrm{P}(\mathrm{T}<=\mathrm{t}) \geq 0.163)$.

Hypothesis $\mathrm{H} 2$ is partially accepted due to the above mentioned findings.

Table 3 presents a comparison of entrepreneurs' notions about the statement that entrepreneurs have full knowledge of banks' credit criteria for providing loans to SMEs (CRF2).

Table 3

Evaluation of the knowledge of commercial banks' credit criteria

\begin{tabular}{|c|c|c|c|c|}
\hline \multicolumn{5}{|c|}{ Length of operating a business from 1 to 5 years } \\
\hline \multirow{2}{*}{ Characteristics } & \multicolumn{2}{|c|}{ Gender } & \multicolumn{2}{|c|}{ Education } \\
\hline & Men & Women & $\mathrm{OE}$ & $\mathrm{UE}$ \\
\hline Number of entrepreneurs & 151 & 94 & 143 & 102 \\
\hline Score & -32 & -22 & -10 & -44 \\
\hline Mean & -0.212 & -0.234 & -0.067 & -0.431 \\
\hline $\mathrm{t}-$ Statistics & \multicolumn{2}{|c|}{0.538} & \multicolumn{2}{|c|}{2.964} \\
\hline $\mathrm{P}(\mathrm{T}<=\mathrm{t})$ & \multicolumn{2}{|c|}{0.295} & \multicolumn{2}{|c|}{0.002} \\
\hline \multicolumn{5}{|c|}{ Length of operating a business from 6 to 10 years } \\
\hline \multirow{2}{*}{ Characteristics } & \multicolumn{2}{|c|}{ Gender } & \multicolumn{2}{|c|}{ Education } \\
\hline & Men & Women & $\mathrm{OE}$ & UE \\
\hline Number of entrepreneurs & 138 & 53 & 131 & 60 \\
\hline Score & -39 & -25 & -48 & -16 \\
\hline Mean & -0.283 & -0.472 & -0.350 & -0.296 \\
\hline $\mathrm{t}-$ Statistics & \multicolumn{2}{|c|}{2.441} & \multicolumn{2}{|c|}{0.441} \\
\hline $\mathrm{P}(\mathrm{T}<=\mathrm{t})$ & \multicolumn{2}{|c|}{0.015} & \multicolumn{2}{|c|}{0.659} \\
\hline \multicolumn{5}{|c|}{ Length of operating a business over 10 years } \\
\hline \multirow{2}{*}{ Characteristics } & \multicolumn{2}{|c|}{ Gender } & \multicolumn{2}{|c|}{ Education } \\
\hline & Men & Women & $\mathrm{OE}$ & UE \\
\hline Number of entrepreneurs & 572 & 133 & 475 & 230 \\
\hline Score & -25 & -13 & -38 & -26 \\
\hline Mean & -0.044 & -0.098 & -0.290 & -0.433 \\
\hline $\mathrm{t}$ - Statistics & \multicolumn{2}{|c|}{0.915} & \multicolumn{2}{|c|}{0.803} \\
\hline $\mathrm{P}(\mathrm{T}<=\mathrm{t})$ & \multicolumn{2}{|c|}{0.361} & \multicolumn{2}{|c|}{0.405} \\
\hline
\end{tabular}

Notes: OE - Other education, UE - University education.

There are some partial statistically significant differences in entrepreneurs' notions about having full knowledge of banks' credit criteria in the group of entrepreneurs by gender (operating a business from 6 to 10 years: $\mathrm{P}(\mathrm{T}<=\mathrm{t})$ je 0.015 ) and education (length of operating a business from 1 to 5 years: $\mathrm{P}(\mathrm{T}<=\mathrm{t}$ ) je $0.002)$.

In Group A, entrepreneurs with a university degree were less prone to agree with the claim that they have full knowledge of banks' credit criteria, compared to other entrepreneurs. In group B, women were less prone to agree with the claim that entrepreneurs know banks' credit criteria, compared to men. 
There are no statistically significant differences in entrepreneurs' notions about having full knowledge of banks' credit criteria, in relation to selected statistical characteristics (gender and education) in the group of entrepreneurs operating a business for over 10 years (gender: $\mathrm{P}(\mathrm{T}<=\mathrm{t})$ is 0.361 and education: $\mathrm{P}(\mathrm{T}<=\mathrm{t})$ is 0.405$)$.

Hypothesis H3 is partially accepted due to the above mentioned findings.

Table 4 presents a comparison of entrepreneurs' notions about the statement that banks' credit criteria for providing financing to SMEs are transparent (CRF3).

Table 4

Evaluation of the transparency of commercial banks' credit criteria

\begin{tabular}{|c|c|c|c|c|}
\hline \multicolumn{5}{|c|}{ Length of operating a business from 1 to 5 years } \\
\hline \multirow{2}{*}{ Characteristics } & \multicolumn{2}{|c|}{ Gender } & \multicolumn{2}{|c|}{ Education } \\
\hline & Men & Women & $\mathrm{OE}$ & $\mathrm{UE}$ \\
\hline Number of entrepreneurs & 151 & 94 & 143 & 102 \\
\hline Score & 6 & -2 & 11 & -7 \\
\hline Mean & 0.0397 & -0.021 & 0.077 & -0.069 \\
\hline $\mathrm{t}-$ Statistics & \multicolumn{2}{|c|}{0.997} & \multicolumn{2}{|c|}{2.360} \\
\hline $\mathrm{P}(\mathrm{T}<=\mathrm{t})$ & \multicolumn{2}{|c|}{0.160} & \multicolumn{2}{|c|}{0.009} \\
\hline \multicolumn{5}{|c|}{ Length of operating a business from 6 to 10 years } \\
\hline \multirow{2}{*}{ Characteristics } & \multicolumn{2}{|c|}{ Gender } & \multicolumn{2}{|c|}{ Education } \\
\hline & Men & Women & $\mathrm{OE}$ & $\mathrm{UE}$ \\
\hline Number of entrepreneurs & 138 & 53 & 131 & 60 \\
\hline Score & 2 & 0 & -6 & 8 \\
\hline Mean & 0.015 & 0 & -0.046 & 0.133 \\
\hline $\mathrm{t}-$ Statistics & \multicolumn{2}{|c|}{0.198} & \multicolumn{2}{|c|}{2.391} \\
\hline $\mathrm{P}(\mathrm{T}<=\mathrm{t})$ & \multicolumn{2}{|c|}{0.843} & \multicolumn{2}{|c|}{0.017} \\
\hline \multicolumn{5}{|c|}{ Length of operating a business over 10 years } \\
\hline \multirow{2}{*}{ Characteristics } & \multicolumn{2}{|c|}{ Gender } & \multicolumn{2}{|c|}{ Education } \\
\hline & Men & Women & $\mathrm{OE}$ & UE \\
\hline Number of entrepreneurs & 572 & 133 & 475 & 230 \\
\hline Score & 66 & 8 & 41 & 33 \\
\hline Mean & 0.115 & 0.06 & 0.086 & 0.143 \\
\hline $\mathrm{t}-$ Statistics & \multicolumn{2}{|c|}{0.905} & \multicolumn{2}{|c|}{1.161} \\
\hline $\mathrm{P}(\mathrm{T}<=\mathrm{t})$ & \multicolumn{2}{|c|}{0.366} & \multicolumn{2}{|c|}{0.246} \\
\hline
\end{tabular}

Notes: OE - Other education, UE - University education.

There are some partial statistically significant differences in entrepreneurs' notions about banks' credit criteria for providing financing to entrepreneurs being transparent in relation to the highest attained education level in the group of entrepreneurs operating a business from 1 to 10 years (from 1 to 5 years: $\mathrm{P}(\mathrm{T}<=\mathrm{t})=0.009$, from 6 to 10 years: $\mathrm{P}(\mathrm{T}<=\mathrm{t})=0.017)$

Entrepreneurs with a lower level of attained education view commercial banks' credit criteria as more transparent compared to entrepreneurs with a university degree (Group A).

On the contrary, Group B entrepreneurs with a university degree view commercial banks' credit criteria as more transparent compared to other entrepreneurs.

In Group C, the entrepreneurs' gender or attained education level have no influence on the evaluation of commercial banks' credit criteria transparency.

Hypothesis H4 is partially accepted due to the above mentioned findings. 


\section{DISCUSSION}

The basic findings from the empirical research can be summarized as follows:

- Entrepreneurs have a quite high perception of the significance of credit risk during crisis, which determines their entrepreneurship ( $63.5 \%$ of respondents agreed with this statement);

- SMEs' knowledge of credit criteria is still low (only $29 \%$ of respondents);

- Entrepreneurs are somewhat critical in their evaluation of credit criteria transparency (only $30 \%$ of them agreed with the claim that banks' credit criteria are transparent).

- It was discovered that the length of operating a business has an influence on the evaluation of important credit risk factors. Entrepreneurs operating a business for over 10 years (Group C) have a higher perception of the significance of credit risk in the current era, have better knowledge of banks' credit criteria, and view credit criteria as more transparent, compared to Group A (beginner entrepreneurs).

- Some partial differences were discovered in the evaluation of important credit risk factors in the entrepreneur groups (A and B) based on entrepreneurs' gender and attained education level. Experienced entrepreneurs, meaning those operating a business for over 10 years, evaluate defined credit risk factors equally.

The results of this research are to a certain degree compatible with the findings by North, Baldock, and Ekanem (2010) regarding young enterprises' notions about external credit sources, and complement other authors' views (Carter, Shaw, Lam, and Wilson, 2007; Van der Sluis, and Van Praag, 2008; Kato, Okamuro, and Honjo, 2015) on the significance of education for operating a business in the SME segment.

The results also draw attention to the need to increase the quality of communication between banks and SMEs and make it more intensive and transparent. This calls for the creation of consulting centers by state authorities and banks whose aim would be providing better information about credit options, thorough consultations and support in preparing high quality business plans, especially in case of SMEs' investment and development activities which banks tend to consider very carefully. Joint participation in business development requiring banks' participation in the early stages of entrepreneurship can be an innovation for the Czech Republic, while such centers have long yielded positive results abroad.

Having full knowledge of credit criteria for providing a loan to a business is one of the key factors of accepting the credit limit. The results indicate that entrepreneurs do not think they have full knowledge of these criteria. Other important factors for bank institutions are the following: the enterprise's financial history which grows linearly with the time the enterprise is being run in the business environment (North, Baldock, and Ekanem, 2010), the option of distributing the capital stake to more than one person in a small business (Jinjarak and Wiganraja, 2016), market share growth in the export of products to other countries (Yildirim, Akci, and Eksi, 2016).

On one hand, entrepreneurs constantly look for opportunities to maximize profit; on the other hand, state should ensure that businesses receive support especially during a crisis period and have access to alternative means of support such as help form non-profit organizations and new bank products for entrepreneurs, as described by Casay and Toole (2014) in their research.

In this context Radas, Anic, Tafro, and Wagner (2015) point out the positive effect of public support program on the innovation performance of the SMEs in Croatia. They find that firms receiving direct financial support from the government have more output from $R \& D$ expenditures, which stimulates innovation propensity of the SMEs. They also find that firms receiving both direct financial support and tax credit facility are superior in terms of innovation performance to the firms that do not receive any of the facilities. Hence, authors argue that government financial support can directly affect the innovation propensity of the SMEs because of financial incentives. 


\section{CONCLUSION}

The aim of this paper was to define important areas of credit risk in the SME segment and to quantify differences in entrepreneurs' notions in regard to the length of operating a business and the entrepreneurs' gender and attained education level.

Some scientific findings can be formed on basis of this empirical research:

Small and medium-sized enterprises have a higher perception of the significance of credit risk compared to a pre-crisis era. At the same time, a significant shift in the management of credit risk cannot be expected in these enterprises, as the SMEs' knowledge of credit criteria is quite low.

Another problem in this field is a quite low transparency of credit relations. Entrepreneurs claim that banks' credit criteria are not very transparent. Banks, on the other hand, see a problem with SMEs not providing quality information. Another issue is the business field which determines the banks' attitude towards providing credit. This dimension is the subject of a subsequent research.

Based on research findings, the length of operating a business has a significant influence on the evaluation of credit risk factors. Experienced entrepreneurs, meaning those operating a business for over 10 years have a more intense perception of the significance of credit risk in the current era, have better knowledge of banks' credit criteria, and view credit criteria as more transparent than beginner entrepreneurs This is to a certain degree connected with psychosocial factors which influence the level of self-confidence in business activities, propensity for risk taking, etc.

An interesting finding is that the length of operating a business reduces the differences in the evaluation of important credit risk factors in regard to entrepreneurs' gender and age.

This research has its limitations, but can nevertheless serve as inspiration for further evaluation of SMEs' attitude towards external financing, and can motivate commercial banks to optimize their loan processes. Another great benefit of this research is that its results can serve for authors of economic and financial politics on a macro-level, and those dealing with the creation of national policies aimed at SMEs' development on the micro-level.

\section{REFERENCES}

Armstrong, A., Davis, E. P., Liadze, I., \& Rienzo, C. (2013). An assessment of bank lending to UK SMEs in the wake of the crisis. National Institute Economic Review, 225(1), 39-61. https://doi.org/10.1177/002795011322500106

Ayub, A., Razzaq, A., Aslam, M. S., \& Iftekhar, H. (2013). Gender effects on entrepreneurial orientation and value innovation: evidence from Pakistan. European Journal of Business and Social Sciences, 2(1), 82-90.

Bain \& Company, Inc. and The Institute of International Finance. (2013). Restoring Financing and Growth to Europe's $\quad$ SMEs. Retrieved from http://www.bain.com/Images/REPORT_Restoring_financing_and_growth_to_Europe's_SMEs.pdf

Balcaen, S., Ooghe, H. (2006). 35 years of studies on business failure: An overview of the classic statistical methodologies and their related problems. British Accounting Review, 38(1), 63-93. http://dx.doi.org/doi:10.1016/j.bar.2005.09.001

Balcerzak, A. P., Kliestik, T., Streimikiene, D., \& Smrčka, L. (2017). Nonparametric approach to measuring efficiency of banking sectors in European Union countries. Acta Polytechnica Hungarica, 14(7), 51-70.

Beck, T. (2013). Bank financing for SMEs - lessons from the literature. National Institute Economic Review, 67(1), $23-38$.

Belás, J., Gavurova, B., Schonfeld, J., Zvarikova, K., \& Kacerauskas, T. (2017). Social and economic factors affecting the entrepreneurial intention of university students. Transformations in Business and Economics, 16(3), 220-239.

Belás, J., Macháček, J., Bartoš, P., Hlawiczka, R., \& Hudáková, M. (2014). Business risks and the level of entrepreneurial optimism of SME in the Czech and Slovak Republic. Journal of competitiveness, 6(2), 30-41.

Carter, S., Shaw, E., Lam, W., \& Wilson, F. (2007). Gender, Entrepreneurship, and Bank Lending: The Criteria and Processes Used by Bank Loan Officers in Assessing Applications. Entrepreneurship Theory and Practice, 31(3). http://dx.doi.org/10.1111/j.1540-6520.2007.00181.x 
Casey, E., O., \& Toole, C. M. (2014). Bank lending constraints, trade credit and alternative financing during the financial crisis: Evidence from European SMEs. Journal of Corporate Finance, 27, 173-193. http://dx.doi.org/10.1016/i.jcorpfin.2014.05.001

Cwynar, A., Cwynar, W., Wais, K., \& Parda, R. (2016). Loan Perception and Loan-Related Attitude of Poles: Evidence from the Field. Forum Scientiae Oeconomia, 4(2), 37-58.

Deakins, D., Whittam, G., \& Wyper, J. (2010). SMEs access to bank finance in Scotland: an analysis of bank manager decision making. Venture Capital, 13(3), 193-209. http://dx.doi.org/10.1080/13691061003658647

Dobeš, K., Kot, S., Kramoliš, J., Sopková, G. (2017). The Perception of Governmental Support in The Context of Competitiveness of SMEs in the Czech Republic. Journal of Competitiveness, 9(3), 34-50. http://dx.doi.org/10.7441/joc.2017.03.03

European Association of Craft, SMEs. (2007). Crafts, Trades and SMEs need better access to finance. Retrieved from www.ueapme.com/.../041027_SME-finance_final.d

Gavurova, B., Belas, J., Kocisova, K., Kliestik, T. (2017). Comparison of Selected Methods for Performance Evaluation of Czech and Slovak Commercial Banks. Journal of Business Economics and Management, 18(5), 852-876 http://dx.doi.org/10.3846/16111699.2017.1371637

Global Markets Institute. (2014). Giving credit where it is due How closing the credit gap for women-owned SMEs can drive global growth. New York: Goldman Sachs International.

Gorzen-Mitka, I. (2015). Leading risk management determinants of small and medium-sized enterprises (SMEs): An exploratory study in Poland. Eurasian studies in Business and Economics, 3(1), 289-298. http://dx.doi.org/10.1007/978-3-319-27570-3 23

Greene, F. J., \& Saridakis, G. (2008). The role of higher education skills and support in graduate selfemployment. Studies in Higher Education, 33(6), 653-672. http:// dx.doi.org/10.1080/03075070802457082

Haghani, S. (2016). Estimation of the probability of credit card charge-off in the presence of competing risks. Banking and Finance Review, 8(2), 51-80. http://dx.doi.org/10.2139/ssrn.2576182

Irwin, D., \& Scott, J. M. (2010). Barriers faced by SMEs in raising bank finance. International Journal of Entrepreneurial Behavior and Research, 16(9), 245-259. http://dx.doi.org/10.1108/13552551011042816.

Jinjarak, Y., \& Wiganraja, G. (2016). An empirical assessment of the export- financial constraint relationship: How different are small and medium enterprises. World Development, 79. http://dx.doi.org/10.1016/i.worlddev.2015.11.012.

Kato, M., Okamuro, H., \& Honjo, Y. (2015). Does Founder Human Capital Matter for Innovation? Evidence from Japanese Start-ups. Journal of Small Business Management, 53(1), 114-128. http://dx.doi.org/10.1111/jsbm.12094

Karaev, A., Melnichuk, M., Guev, T. \& Mentel, G. (2017). Stability analysis of the banking system: a complex systems approach. Journal of International Studies, 10(3), 273-284. http://dx.doi.org/10.14254/2071-8330.2017/10-3/20

Kliestik, T., Misankova, M., Valaskova, K., \& Svabova, L. (2018). Bankruptcy prevention: new effort to reflect on legal and social changes, Science and Engineering Ethics, 24(2), 791-803. http://dx.doi.org/10.1007/s11948-017-9912-4

Kliestikova, J., Misankova, M., \& Kliestik, T. (2017). Bankruptcy in Slovakia: international comparison of the creditor's position. Oeconomia Copernicana, 8(2), 221-237. http://dx.doi.org/10.24136/oc.v8i2.14

Ključnikov, A., Belás, J., Kozubíková, L., \& Paseková, P. (2016). The Entrepreneurial Perception of SME Business Environment Quality in the Czech Republic. Journal of Competitiveness, 8(1), 66-78. http://dx.doi.org/10.7441/joc.2016.01.05

Kozubíková, L., Homolka, L., \& Kristalas, D. (2017). The Effect of Business Environment and Entrepreneurs' Gender on Perception of Financial Risk in The SMEs Sector. Journal of Competitiveness, 9(1), 36-50. http://dx.doi.org/10.7441/joc.2017.01.03

Kozubíková, L., Belás, J., Bilan, Y., \& Bartoš, P. (2015). Personal characteristics of entrepreneurs in the context of perception and management of business risk in the SME segment. Economics and Sociology, 8(1), 41-54. http://dx.doi.org/10.14254/2071- 789X.2015/8-1/4

Kreiser, P. M., Marino, L. D., Dickson, P., \& Weaver, K. M. (2010). Cultural influences on Entrepreneurial orientation: the impact of national culture on risk taking and proactiveness in SMEs. Entrepreneurship Theory and Practice, 34(5), 959-983. http://dx.doi.org/10.1111/j.1540-6520.2010.00396.x

Maciag, J., \& Löderbusch, M. (2017). A latent variable credit risk model comprising nonlinear dependencies in a sector 
framework with a stochastically dependent loss given default. Journal of Credit Risk, 13(4), 37-74. http://dx.doi.org/10.21314/JCR.2017.229

Mardika, D.R.W., Damayanti, T.W., \& Supramono, L. (2018) Understanding the determinant of SME owners' intention to have bank credit. Polish Journal of Management Studies, 17(1), 165-174. http://dx.doi.org/10.17512/pjms.2018.17.1.14

Mentel, G., \& Brożyna, J. (2015). Compatibility of market risk measures. Journal of International Studies, 8(2), 52-62.

Neuberger, D., \& Räthke, S. (2009). Microenterprises and multiple relationships: The case of professionals. Small Business Economics, 32(2), 207-229. http://dx.doi.org/10.1007/s11187-007-9076-8

North, D., Baldock, R., \& Ekanem, I. (2010). Is there a debt finance gap relating to Scottish SMEs? A demand side perspective. Venture Capital-An international journal of entrepreneurial finance. Taylor Francis Online, 12(3), 173-192. https://doi.org/10.1080/13691061003658670

Pavlov, A., Steiner, E., \& Wachter, S. (2015). Macroeconomic risk factors and the role of mispriced credit in the returns from international real estate securities. Real Estate Economics, 43(1), 241-270. http://dx.doi.org/10.1111/1540$\underline{6229.12084}$

Perez, J. A., Alarcon, D. C., \& Umali, M. A. S. (2017). Determining the credit risk factors in accessing debt financing for entrepreneurial activities. DLSU Business and Economics Review, 27(1), 89-96.

Rad, A., Yazdanfar, D., \& Öhman, P. (2014). Female and male risk aversion. International Journal of Gender and Entrepreneurship, 6(2). http://dx.doi.org/10.1108/IJGE-02-2013-0012.

Radas, S., Anic, I., Tafro, A., \& Wagner, V. (2015). The effects of public support schemes on small and medium enterprises. Technovation, 38. http://dx.doi.org/10.1016/j.technovation.2014.08.002

Rizos, V., Behrens, A., Van der Gaast, V., Hofman, E., et al. (2016). Implementation of circular economy business models by small and medium-sized enterprises (SMEs): Barriers and Enablers. Sustainability, 8(11). http://dx.doi.org/10.3390/su8111212.

Siekelova, A., Kliestik, T., Svabova, L., Androniceanu, A., \& Schönfeld, J. (2017). Receivables management: The importance of financial indicators in assessing the creditworthiness. Polish Journal of Management Studies, 15(2), 217-228. http://dx.doi.org/10.17512/pjms.2017.15.2.20

Yasnolob, I., \& Radionova, Y. (2017). The organizational fundamentals of innovation development management of agro-industrial enterprises.Economics, Management and Sustainability, 2(1), 60-66. doi:10.14254/jems.2017.2-1.5.

Yildirim, H. S., Akci, Y., \& Eksi, I. H., (2013). The Effect of Firm Characteristics in Accessing Credit for SMEs. Journal of Financial Services marketing, 18(1). http://dx.doi.org/10.1057/fsm.2012.28

Van der Sluis, J., \& Van Praag, M. (2008). Education and Entrepreneurship Selection and Performance: A Review of the Empirical Literature. Journal of Economic Surveys, 22(5), 795-841. http://dx.doi.org/10.1111/j.14676419.2008.00550.x 